\title{
Identification of Mal d 1Apple Allergens with PCR-techniques
}

\author{
E. E. Szabó ${ }^{1}$, K. Takács ${ }^{1}$, E. Kovács ${ }^{2}$ and É. Gelencsér ${ }^{1}$ \\ ${ }^{1}$ Central Food Research Institute, Department of Biology, H-1022 Budapest Herman Ottó út 15, Hungary and ${ }^{2}$ Corvinus \\ University of Budapest, Faculty of Food Science Department of the Postharvest Science and Technology, H-1118 Budapest \\ Ménesi út 45/F, Hungary
}

Apple is one of the most important fruit grown and consumed in temperate climate region, and recommended as a curiously healthy fruit to reduce the risk of cardiovascular diseases and several types of cancer. Nevertheless about $2 \%$ of European population suffers from several allergenic reactions after eating from freshly picked apple. In apple there are four main allergen families, which have been already identified. Mal d 1 and Mal d 3 are the major apple allergen families. Mal d 1 is a homologue of sensitizing Bet $\mathrm{v} 1$ birch pollen allergen and cause II. type food allergic symptoms (e.g. oral allergy syndrome, OAS) in birch-pollen sensitized patients. Mal d 1 and Bet v 1 proteins belongs to pathogenesis related proteins (PR-10 family), as expression of these genes are generated by several biotic and abiotic factors. The Mal d 1 genes involve a large family, which can be divided into 4 subfamilies with 18 members. These 4 subfamilies comprise 7 intron containing and 11 intronless members that have been mapped in clusters on three linkage groups. Mal d 1 allergens are $17-18 \mathrm{kDa}$ molecular weight proteins of 158-159 amino acid components, encoded by $480-483$ nucleotids. Mal d 1 allergy is predominant in Central and Northern Europe. The intensity of triggered allergenic reaction is depend on several factors e.g. apple cultivars, storage condition.

In our research we studied the occurrence of the 7 main Mal d 1 apple allergens in 24 different and most preferably consumed and some special Hungarian apple varieties. The first step of identification of apple allergens by PCR analysis is the DNA isolation from samples. In this study the DNA was extracted according to Wizard DNA Clean-up System. The DNA solutions were characterized by using UVspectroscopy and agarose gel electrophoresis. The concentration and purity of DNA solution were determined by UV-spectroscopy (UV1601, Shimadzu) relating to the absorbance measured at 260 and $280 \mathrm{~nm}$, respectively. The purity of the DNA solution was appropriate if the calculated absorbance ratio was between 1.7 and 2.0. The DNA degradation was identified by electrophoretic separation on $1 \%$ agarose gel. To determine the presence of Mal d 1 allergenic protein-coding DNA sequences different primer pairs were chosen in each case. The amplified products given by PCR reactions were identified with agarose and polyacril-amid gel electrophoresis.

According to our results, the least fragments were observed at Goldstar, Braeburn and Redspur Telligent apples. All studied apple allergenic protein-coding gene were identified in the case of five apples: Elstar, Red Jonagold, Gala, Alant apple and Gravenstein, so these probably belong to high allergen-protein containing apple varieties.

Detection of Mal d 1.06 gene results polymorph pattern, which is able to identify low allergen-protein containing apple sample. We could detect the presence of $154 \mathrm{nt}$ marker gene related to the low Mal d 1 allergen protein content at more than half of the examined apple samples, but these samples contained another allele next to the $154 \mathrm{nt}$ allele, which allele is able to modify the property of $154 \mathrm{nt}$ allele. Exclusively, in homozygote form, only one examined apple variety - Florina - contained the 154 nt gene related to the low Mal d 1 allergen protein content, so this apple variety probably has low Mal d 1 allergen protein content. The confirmation study of the presence of potential apple allergens by RNA and protein techniques is our plan in near future. 